\title{
Article
}

\section{ESG Disclosures and Stock Price Crash Risk}

\author{
Rio Murata and Shigeyuki Hamori * (10)
}

\author{
Graduate School of Economics, Kobe University, 2-1, Rokkodai, Nada-Ku, Kobe 657-8501, Japan; \\ rio.murata.kobeu@gmail.com \\ * Correspondence: hamori@econ.kobe-u.ac.jp
}

\section{check for} updates

Citation: Murata, Rio, and Shigeyuki Hamori. 2021. ESG Disclosures and Stock Price Crash Risk. Journal of Risk and Financial Management 14: 70. https://doi.org/10.3390/jrfm14020070

Academic Editor: Thanasis Stengos

Received: 11 January 2021

Accepted: 4 February 2021

Published: 7 February 2021

Publisher's Note: MDPI stays neutral with regard to jurisdictional claims in published maps and institutional affiliations.

Copyright: (c) 2021 by the authors. Licensee MDPI, Basel, Switzerland. This article is an open access article distributed under the terms and conditions of the Creative Commons Attribution (CC BY) license (https:// creativecommons.org/licenses/by/ $4.0 /)$.

\begin{abstract}
In this study, we investigate the relationship between environmental, social, and governance (ESG) disclosures and stock price crash risk. A stock price crash is a dreadful event for market participants. Thus, exploring stock price crash determinants is helpful for investment decisions and risk management. In this study, we use samples of major market index components in Europe, the United States, and Japan to perform regression analyses, after controlling for other potential stock price crash determinants. We estimate static two-way fixed-effect models and dynamic GMM models. We find that coefficients of firm-level ESG disclosures are not statistically significant in the static model. ESG disclosure coefficients in the dynamic model are not statistically significant in the U.S. market sample. On the other hand, coefficients of ESG disclosure scores in the dynamic model are statistically significant and negative in the European and Japanese marker sample. Our findings suggest that ESG disclosures lower future stock price crash risk; however, the effect and predictive power of ESG disclosures differ among regions.
\end{abstract}

Keywords: ESG; stock price crash risk; crash risk measure

\section{Introduction}

Sustainable investment, including socially responsible investments (SRIs), corporate social responsibility (CSR) investments, and environmental, social, and governance (ESG) investments, have engaged interest in financial markets. ESG investment is an investment approach that considers environmental, social, and governance factors in its analysis, selection, and management. ESG investing has attracted a great deal of attention, especially since the UN Principles of Responsible Investment (UNPRI) launch in April 2006 at the New York Stock Exchange. The process to develop the PRI started in early 2005, under the United Nations Secretary-General Kofi Annan (PRI n.d.). It is composed of six principles, which are compiled in Table 1. ESG investing has developed based on the idea that companies need to consider their corporate business from the perspective of the three ESG factors in order to ensure their sustainability.

The investment strategies of ESG investing are generally categorized into six or seven types (Boffo and Patalano 2020; Global Sustainable Investment Alliance 2018). Here, we explain the strategies in seven categories. The first strategy is "Negative/Exclusionary Screening", which involves the removal of specific sectors, companies, or practices from a fund or portfolio, according to specific ESG criteria. "Positive/Best-In-Class Screening" is an approach which invests in sectors, companies, or projects selected for positive ESG performance by comparison among industrial sectors. "Norms-Based Screening" involves the screening of investments above criteria of business practices based on international norms such as those published by the OECD and UN. Norms-based screening includes positive/best-in-class screening in some of the literature. "ESG Integration" involves the systematic and explicit inclusion of ESG factors in the investment process. "Sustainability Themed Investing" involves investing in environmental, social, or governance areas related to sustainability, such as clean energy and green technology. "Impact Investing" aims at social or environmental problems, often for social impact. The last is "Corporate 
Engagement and Shareholder Action," using shareholder power to influence corporate behaviors based on comprehensive ESG guidelines.

Table 1. The six principles of responsible investment.

\begin{tabular}{cl}
\hline Principle 1 & $\begin{array}{l}\text { We will incorporate ESG issues into investment analysis and decision-making } \\
\text { processes. }\end{array}$ \\
Principle 2 & $\begin{array}{l}\text { We will be active owners and incorporate ESG issues into our ownership policies } \\
\text { and practices. }\end{array}$ \\
Principle 3 & $\begin{array}{l}\text { We will seek appropriate disclosure on ESG issues by the entities in which we } \\
\text { invest. }\end{array}$ \\
Principle 4 & $\begin{array}{l}\text { We will promote acceptance and implementation of the Principles within the } \\
\text { investment industry. }\end{array}$ \\
Principle 5 & $\begin{array}{l}\text { We will work together to enhance our effectiveness in implementing the } \\
\text { Principles. }\end{array}$ \\
Principle 6 & $\begin{array}{l}\text { We will each report on our activities and progress towards implementing the } \\
\text { Principles. }\end{array}$ \\
\hline Note: source: PRI homepage.
\end{tabular}

Some people can be confused about the differences between some concepts, such as SRI, CSR, and ESG, related to sustainable investing. Socially responsible investment (SRI) has its roots in the practices of religious believers and ethical exclusion (Chidi 2018; Fulton et al. 2013; Oonishi and Umeda 2018). For example, churches in the United States opposed gambling, alcohol, and tobacco in the 1920s. During the 1960s and 1970s, SRI developed in the United States. Some investors avoided investing in certain industries, such as the military industry, under the civil rights movement and movements against the Vietnam war. During these early periods, SRI was an exclusionary investment approach, considering ethical, social, and environmental factors. SRI has been developing to its current form, which adopts a mixture of positive and negative screening approaches to maximize financial returns, since the 1990s. An investment approach considering environmental, social, and governance factors (named ESG) has been studied since around 2006. Although some refer to ESG investing as one of the approaches of SRI investment, they are different. While SRI investing is more associated with screening approaches and focuses on ethical, social, or environmental practices, ESG investing has more investment approaches and uses ESG criteria to enhance returns and manage risks better.

There are varieties of definitions of ESG argued in the literature (Boffo and Patalano 2020; Global Sustainable Investment Alliance 2018; Ministry of the Environment Government of Japan 2020). ESG is a concept in the financial intermediation chain. Issuers provide information regarding environmental, social, and governance factors and receive ESG ratings. Investors, rating providers, and other financial market participants request information regarding ESG and consider them to decide on their investment behaviors. On the other hand, corporate social responsibility (CSR) is a concept relating to the relationship between companies and stakeholders. There are varieties of definitions of CSR published by academics and institutions (Ministry of the Environment Government of Japan 2020; Oonishi and Umeda 2018; Yoshida 2019). Firms which have a significant presence (i.e., in society and economy) can influence many stakeholders, from consumers to the regional ecosystem. Therefore, firms should consider not only the corporate economic profits, but also the society and environment, in order to coexist with stakeholders, in order to enhance their firm values with more balanced growth among the economy, society, and environment. Firm CSR activities depend on various individual situations and beliefs, as firms are different in all aspects, such as their location, industry, culture, and religion. Although both ESG and CSR are concepts that aim at developing sustainable societies, what firms are closely related to in each concept is different; that is, financial intermediation chains and stakeholders, respectively.

The Sustainable Development Goals (SDGs) are also closely related to ESG investing. The 2030 Agenda for Sustainable Development-a plan to act for people, the planet, and 
prosperity—was formally adopted at the UN Summit held in September 2015 (United Nations 2015). From developed countries to developing countries, all countries and stakeholders will implement this plan from 2016 to 2030. It is composed of 17 sustainable development goals and 169 targets for a balanced society in three aspects: economy, society, and environment. This involves the pledge that "no one will be left behind". The establishment of the SDGs is one factor which has made ESG investing draw more interest in financial markets.

As ESG approach has attracted attention and grown in financial markets; the number of published multidisciplinary literature on ESG and its impact on firm actions and outcomes has also increased. Some studies have focused on the relationships between corporate social performance and corporate financial performance, while others have focused on the relationships between ESG and the cost of capital. This study focuses on the relationship between ESG and firm risk; in particular, stock price crash risk. Extreme drops in price in the stock market are known as crashes. Investigating crash risk provides information on asymmetry in risks, especially downside risks. Therefore, the study of stock price crash risk can help investors to better make decisions and manage risks.

Crashes are dreadful events for market participants. This kind of negative movement can occur at an aggregate market level or at the single stock level. When an investor with a large position in a stock suffers a significant crash, it can have a considerable influence on their reputational capital. Unfortunately, the movements in stock markets tend to be decreases rather than increases. The distribution of stock returns is asymmetric. Stock prices are prone to crashes.

According to the model developed by Jin and Myers (2006), the existence of abrupt stock price drops in firms can be explained by the information asymmetry between inside managers and outside investors. Firm managers, for their own sake, tend to hide bad news from outside investors and, when it reaches a limit to keep hiding the news, the accumulated news comes out, thus bringing on crashes (Hutton et al. 2009; Jin and Myers 2006). Although they should avoid crashes, it is difficult for investors to guess which firms and managers are withholding bad news, as it is inside information. Some researchers have carried out research to discover common determinants or factors of stock price crashes.

Several research studies have studied the relationships among firm activities for sustainability or social responsibility, bad news hoarding behaviors of firm managers, and corporate finance report transparency. Firms with more socially responsible behaviors tend to provide more transparent financial reporting information (Gelb and Strawser 2001; Kim et al. 2012). Kim et al. (2014) found that firms with better CSR performances were associated with lower stock price crash risk. On the other hand, there exists a concern that firms that seem socially responsible may not be ethical (Hemingway and Maclagan 2004; Prior et al. 2008). They may use CSR as a tool to divert the attention of stakeholders from corporate bad behavior or information. In this case, better CSR performance may not be associated with better financial performance.

This study focuses on ESG disclosures, as it seems useful as an indicator of corporate ethical behavior. Several rating providers provide ESG scores evaluated using unique methodologies. The ESG disclosure ratings are based only on the level of corporate disclosures related to environmental, social, and governance factors. It appears that firms that are active with respect to ESG issues are socially responsible. Further, the disclosure level can reflect the corporate tendency of information supply. More active firms regarding ESG issues are more socially responsible; these firms are generally also ethical in terms of financial reporting. Therefore, we should expect that firms with higher ESG disclosure scores are associated with lower stock price crash risk.

In this study, we investigate the relationships between ESG disclosures and stock price crash risk in three regions: Europe, the United States, and Japan. Although these three regions are common in holding more considerable sustainable investment assets, they also show significant differences. According to the Global Sustainable Investment Review 2018 released by the Global Sustainable Investment Alliance (2018), these three countries had the 
largest sustainable investment assets, considering ESG factors, in the five major markets in 2018. Europe had the largest assets, about USD 14,075 billion, the United States had about USD 11,995 billion of assets, while Japan had about USD 2180 billion of assets. While the proportion of sustainable investment (relative to total managed assets) for Europe was $48.8 \%$, that in the other two regions was much lower: $25.7 \%$ in the United States and $18.3 \%$ in Japan in 2018. We consider that comparisons among regions can provide new insights regarding stock price crash determinants.

We performed regression analyses on the effects of ESG disclosures with samples of the listed firms on major market indexes in Europe, the United States, and Japan. We employed both static two-way fixed-effect models and dynamic GMM. We controlled for potential stock price crash determinants, found in previous studies in the literature. Coefficients of ESG disclosure scores were not statistically significant in the static model. ESG disclosures coefficients in the U.S. market sample were not statistically significant in the dynamic model. On the other hand, coefficients of ESG disclosures in the European and Japanese market sample were statistically significant and negative in the dynamic model. We found a negative relation between firm-level ESG disclosures and future stock price crash risk in Europe and Japan. Our findings suggest that ESG disclosures are negatively associated with future stock price crash risk; however, the effect and predictive power of ESG disclosures differ among regions.

\section{Literature Review}

\subsection{Stock Price Crash Factors and Bad News Hoarding Theory}

We investigated the literature regarding firm-level factors of stock price crash risk. Chen et al. (2001) developed two measures of crash likelihood: negative coefficient of skewness (NCSKEW) and down-to-up volatility (DUVOL). The authors adopted all NYSE and AMEX firms as a sample and found positive relationships between trading volume, past returns, and firm size with stock price crash risk.

Stock price crashes are closely related to corporate bad news hoarding behaviors. Jin and Myers (2006) developed bad news hoarding theory to explain the existence of firm-level abrupt negative movements in stock prices. According to this theory, several corporate managers may withhold bad news from outside investors. Managers cannot keep hiding bad news from market participants and, when it reaches a limit, the accumulated news is disclosed, thus bringing on a crash in prices. Stocks lacking transparency are more prone to crashes. Some researchers have focused on corporate behavior and bad news hoarding theory to performed analyses on stock price crash factors.

Hutton et al. (2009) investigated the effect of transparency of financial reporting and found that firms with more opaque financial reporting were more prone to stock price crashes. The level of transparency in financial reporting was measured through discretionary accruals. Kim et al. (2011) used U.S. firms as a sample and found a positive relation between tax avoidance and firm-level stock price crash risk. Kim et al. (2014) focused on CSR performance in the U.S. market. The authors concluded that higher CSR firms were likely to exhibit a high standard of transparency and were associated with lower crash risks.

Kim and Zhang (2016) used a sample of U.S. firms and found that conditional accounting conservatism restricted the incentives and unethical behaviors of managers, such as concealing bad news. Thus, accounting conservatism is associated with lower stock price crash risks. There have been other findings related to information hoarding; such as the negative relationship between crash risk and financial statement comparability (Kim et al. 2016) and the positive relationship between ambiguity in financial reporting and crash risk (Ertugrul et al. 2017). Li et al. (2020) focused on the disclosure timing of firms in financial reporting. The authors used a sample of listed Chinese firms and found that switching the disclosure timing of annual reports to distract market attention increased stock price crash risk. 


\subsection{ESG Disclosure}

Several rating providers have evaluated the ESG issues of firms, based on their disclosures or other industry data sources, and published their ratings. Examples of large ESG ratings providers are Bloomberg, MSCI, Sustainalytics, Thomson Reuters, and RobecoSAM. Their rating methodologies are various. Some providers, such as MSCI, determine ESG assessment based on the qualities of the efforts by ESG issuers, while other providers, such as Bloomberg, evaluate their disclosures using quantitative models. Rating providers determine assessments by focusing on a firm's ESG performance, disclosure, or both in their weightings and provide their own ESG scores. Although ESG disclosures and performance can be confused, they are different. The score used in the analysis varies throughout the literature.

For this study, we adopted the Bloomberg ESG disclosure score. Bloomberg disclosure ratings are provided by the Bloomberg database. They focus on the level of firm disclosure of environmental, social, and governance information. Although disclosure scores do not include an evaluation of the qualities of ESG efforts, they are determined in a mechanical process and represent the tendency toward information disclosure. Bloomberg disclosure scores cover a larger number of firms than other rating providers. Furthermore, the Bloomberg database has been widely used in the financial industry and academia. Many studies have used the Bloomberg disclosure scores in their analyses.

Fatemi et al. (2018) investigated the effect of ESG performance and disclosure on firm values for U.S. firms. They discovered the possibility that ESG disclosures dilute the effects of performance in both positive and negative directions. Yuyama et al. (2019) investigated the relationship between ESG disclosures and investment returns in the Japanese stock market and found no significant differences. Eliwa et al. (2019) investigated the relation between ESG performances and disclosures and debt capital costs in 15 EU countries. ESG performance and disclosure did not exhibit significant differences in their study. Boffo and Patalano (2020) argued that the correlation among ESG scores of a firm provided by different rating providers is low. Different rating providers have different rating approaches and, thus, even the ESG performance scores show differences. The relationship between ESG disclosures and performances, therefore, is not yet clear.

\section{Analysis}

\subsection{Data}

All of the data used in this study were retrieved from the Bloomberg database. The data consisted of the major market index compositions in three regions-Europe, the United States, and Japan. The sample for the European region was based on the STOXX Euro 600 index. To explain the major European economy, we adopted listed firms of the STOXX Euro 600 as the sample components for Europe (as of October 2020). For comparison, the United States and Japanese samples were also based on their major market indexes; we adopted the S\&P 500 index components for the U.S. sample and the Nikkei-225 index components for the Japanese sample (as of October 2020).

The STOXX Europe 600 index is a market index which represents the major European markets. It is composed of 600 companies across 17 countries in the European region (Qontigo n.d.). The constituent countries are as follows: Austria, Belgium, Denmark, Finland, France, Germany, Ireland, Italy, Luxembourg, the Netherlands, Norway, Poland, Portugal, Spain, Sweden, Switzerland, and the United Kingdom. The S\&P 500 index is a representative market index in the U.S. market. It consists of 500 leading firms in the U.S. market (Bloomberg Professional Services n.d.). The Nikkei-225 Stock Average is a major market index in the Japanese market. It is a price-weighted index. It is composed of 225 top-rated Japanese companies listed in the first section of the Tokyo Stock Exchange (Bloomberg Professional Services n.d.). 


\subsection{Environmental, Social, and Governance Ratings}

The initial sample consisted of environmental, social, and governance rating data provided by the Bloomberg database. In this study, we used the Bloomberg ESG disclosure score as the initial sample. The Bloomberg database provides a larger number of ESG ratings of firms than other rating providers. Bloomberg ESG data cover more than 11,700 companies in 102 countries (as of July 2020) (Bloomberg Professional Services 2020). Additionally, the Bloomberg ESG disclosure score data are annual data covering over ten years.

The Bloomberg ESG disclosure score data focus on the level of a firm's environmental, social, and governance disclosure, not including assessments of its ESG performance. The score ranges from 0.1 (for companies with the minimum level of the ESG data disclosure) to 100 (for companies with the full extent of the disclosure on every data point collected by Bloomberg). Each data point is weighted by its importance. The score is also adjusted to each industry sector. Thus, each firm is only evaluated for the data which is relevant to its industrial sector.

The Bloomberg database provides ratings for the level of firm disclosure and not only the overall ESG factors, but also the three individual factors of ESG. Thus, we performed analyses using environmental disclosure scores, social disclosure scores, and governance disclosure scores.

\subsection{Crash Risk Measures}

We adopted two measures, based on firm-specific weekly returns (estimated as the residuals from the market model), of firm-specific crash risk, following Chen et al. (2001). They estimated the following expanded market model regression:

$$
r_{j, \tau}=\alpha_{j}+\beta_{1 . j} r_{m, \tau-2}+\beta_{2 . j} r_{m, \tau-1}+\beta_{3 . j} r_{m, \tau}+\beta_{4 . j} r_{m, \tau+1}+\beta_{5 . j} r_{m, \tau+2}+\varepsilon_{j, \tau},
$$

where $r_{j, \tau}$ is the return on stock $j$ in week $\tau$ and $r_{m, \tau}$ is the return on the market index in week $\tau$. Returns on stocks and indexes are basically calculated from the closing prices on Fridays. When there is no closing price on Friday, a closing price which is before and most close to Friday in the week is extracted, instead. In the European market analyses, we set the STOXX Euro 600 as the market index. We also set the S\&P 500 index and the Nikkei-225 index for the U.S. and Japanese markets, respectively. $W_{j, s}$ denotes the firm-specific weekly return for firm $j$ in week $s$, calculated as the natural logarithm of one plus the residual return, $r_{j, \tau}$, from Equation (1).

Equation (1) includes lead and lag terms of the market index. These terms are for solving what we call nonsynchronous trading. Trading in the stock market does not occur synchronously (Lo and MacKinlay 1990). Trading frequencies are different in each stock. The trading intensities for a stock depend on the situation and differ from hour to hour. However, the analyses in this study are based on weekly data. As mentioned above, the stock prices considered are the closing price, which is the last transaction price of a stock in a week. Its actual time is different. This study adopts lead and lag terms of the market indexes, in order to allow for nonsynchronous trading (Dimson 1979).

The first measure of crash risk was the negative coefficient of skewness of firm-specific weekly returns over the year (NCSKEW), which is calculated by taking the negative of the third moment of firm-specific weekly returns for each year as the first step. Then, it is normalized by the standard deviation of firm-specific weekly returns raised to the third power. Thus, the NCSKEW for firm $j$ in year $t$ is calculated using the following equation:

$$
\operatorname{NCSKEW}_{j, t}=\frac{-\left[n(n-1)^{3 / 2} \sum W_{j, \tau}^{3}\right]}{\left[(n-1)(n-2)\left(\sum W_{j, \tau}^{2}\right)^{3 / 2}\right]},
$$

where $n$ denotes the number of weekly returns during year $t$. 
The second measure of crash risk was the down-to-up volatility measure (DUVOL) of the crash likelihood. Firm-specific weekly returns for firm $j$ over a fiscal year period $t$ are divided into two groups: "down" weeks and "up" weeks. Down weeks refer to weeks when the returns are below the annual mean, while up weeks refer to when the returns are above the annual mean. The standard deviation of firm-specific weekly returns is calculated separately for each of the two groups. DUVOL is the natural logarithm of the ratio of the standard deviation in the down weeks to that in the up weeks:

$$
\operatorname{DUVOL}_{j, t}=\log \left\{\frac{\left(n_{u}-1\right) \sum_{\text {Down }} W_{j, \tau}^{2}}{\left(n_{d}-1\right) \sum_{U p} W_{j, \tau}^{2}}\right\},
$$

where $n_{u}$ denotes the number of up weeks in year $t$ and $n_{d}$ denotes the number of down weeks in year $t$. The higher the value of DUVOL, the more significant the crash risk.

When there is even one missing value for firm-specific weekly returns of a firm in a given year, we dropped the crash risk of that year from the dataset. We employed oneyear-ahead NCSKEW or DUVOL as an explained variable in the empirical analyses below. Taking lagged explanatory variables can avoid simultaneity or reverse causality.

\subsection{Explanatory Variables}

The primary explanatory variable was ESG_SCORE, which is the firm-level Bloomberg ESG disclosure scores obtained from Bloomberg database. We used a one-year lag between the explained variable and all of the explanatory variables.

We employed several control variables, which researchers have previously found to have an influence on future crash risk. Following Chen et al. (2001), we used detrended turnover (DTURNOVER), past returns (RETs), and stock volatility (SIGMAR). Turnover is calculated as the monthly trading volume divided by the total number of shares outstanding during the month. DTURNOVER is calculated as the average turnover over the current year minus the average turnover over the previous year. DTURNOVER was considered as it captures the intensity of disagreements among investors.

RET is calculated as the mean of firm-specific weekly returns during a given period multiplied by 100. The authors explained its predictive power through the existence of bubbles; that is, prices fall back to fundamentals. SIGMAR is calculated as the standard deviation of firm-specific weekly returns. The relation of SIGMAR to crash risk differs throughout the literature.

Following Chen et al. (2001) and Hutton et al. (2009), we controlled for firm size (SIZE), price-to-book ratio (PBR), financial leverage (LEV), and returns on assets (ROAs). SIZE is defined as the natural log value of the market value of equity. Although whether the market-to-book or book-to-market ratio is employed as a control variable differs throughout the literature, we employed the price-to-book ratio (PBR) in this study. PBR is defined as the price per share divided by book value per share. In general, a higher PBR indicates overvaluing. Thus, we expected that higher PBR could lead to a crash in prices. LEV is calculated as total long-term debts divided by total assets. ROA is calculated as profit before tax divided by total assets. Glamour stocks are considered more crash-prone.

Following Hutton et al. (2009) and Kim et al. (2014), we employed discretionary accruals absolute value (ABACC). The authors considered ABACC as a proxy for levels of opacity in corporate financial reporting. In this study, we used the absolute discretionary value of cash flow from operating activities minus net income estimated from the Jones model (Dechow et al. 1995) as ABACC. All explanatory variables were obtained from the Bloomberg database or calculated based on data from the Bloomberg database.

\section{Results}

\subsection{Descriptive Statistics}

Table 2 shows descriptive statistics for the Euro STOXX 600 components. The mean values of crash risk measures were 0.1411 for NCSKEW and 0.0856 for DUVOL. The mean 
value of firm-level Bloomberg ESG disclosure scores was 39.7131. The main assumption behind the GMM is that each variable should be stationary (Ahn and Schmidt 1995; Arellano and Bond 1991). The results of a pnael unit root test (Augmented Dickey-Fuller (ADF) test) indicate that each variable has no unit root and thus is stationary in the Euro STOXX 600 sample.

Table 2. Descriptive statistics for Euro STOXX 600 members.

\begin{tabular}{cccccc}
\hline Variable & $\mathbf{N}$ & Mean & Median & Stdev & ADF Test \\
\hline NCSKEW & 5906 & 0.1411 & 0.0913 & 0.9890 & $3723.66^{* * *}$ \\
DUVOL & 5906 & 0.0856 & 0.0773 & 0.7462 & $3667.02^{* * *}$ \\
ESG_SCORE & 5906 & 39.7131 & 40.9091 & 14.9543 & $1781.72^{* * *}$ \\
DTURNOVER & 5906 & -0.0035 & -0.0020 & 0.0300 & $3430.90^{* * *}$ \\
RET & 5906 & -0.0757 & -0.0571 & 0.4731 & $3852.83^{* * *}$ \\
PBR & 5906 & 4.1509 & 2.1941 & 25.6243 & $1774.66^{* * *}$ \\
SIZE & 5906 & 9.2343 & 9.1753 & 1.4548 & $1899.03^{* * *}$ \\
SIGMAR & 5906 & 0.0330 & 0.0291 & 0.0155 & $2259.25^{* * *}$ \\
LEV & 5906 & 18.4030 & 16.7124 & 13.9883 & $2131.79^{* * *}$ \\
ROA & 5906 & 0.0884 & 0.0655 & 0.2017 & $2442.10^{* * *}$ \\
ABACC & 5906 & 0.0575 & 0.0298 & 0.9833 & $3069.21^{* * *}$ \\
\hline
\end{tabular}

Note: NCSKEW is the negative coefficient of skewness of firm-specific weekly returns over the year. DUVOL is the natural logarithm of the ratio of the standard deviation of firm-specific weekly returns in the down weeks to the up weeks. ESG_SCORE is Bloomberg ESG disclosure score from the Bloomberg database. DTURNOVER is the detrended turnover. DTURNOVER is the average turnover over the current year minus the average turnover over the previous year, where turnover is the monthly trading volume divided by the total number of shares outstanding during the month. RET is the mean of firm-specific weekly returns during a given period times 100 PBR is the price per share divided by book value per share. SIZE is the natural logarithm of the market value of equity. SIGMAR is the standard deviation of firm-specific weekly returns. LEV is the total long-term debts divided by total assets. ROA is the profit before tax divided by total assets. ABACC is the absolute discretionary value of cash flow from operating activities minus net income, as estimated by the Jones model. Panel Augmented Dickey-Fuller (ADF) test was performed with a trend and an intercept. ${ }^{* * *}$ reports statistical significance at the $1 \%$ level.

Table 3 provides descriptive statistics for the S\&P 500 components. The mean value of NCSKEW was 0.1238 , while that of DUVOL was 0.0884 . The mean value of ESG disclosure scores was 30.5249, lower than the average ESG disclosure score of the Euro STOXX 600. The standard deviation of the absolute value of discretionary accruals (ABACC) was quite large. A possible cause for this was the difference in calculation. In this study, we substituted the absolute discretionary value of cash flow from operating activities minus net income to ABACC. Panel ADF test results suggest that each variable has no unit root and is stationary in the S\&P 500 sample.

Table 4 reports descriptive statistics for the Nikkei-225 components. The mean values of NCSKEW and DUVOL were 0.0597 and 0.0376, respectively. The average value of ESG disclosure scores was 36.9411. The average ESG disclosure score for the Nikkei-225 was higher than that of the S\&P 500 and lower than that of the Euro STOXX 600. As well as the Euro STOXX 600 and S\&P 500, each variable in the Nikkei-225 sample has no panel unit root and is stationary. 
Table 3. Descriptive statistics for S\&P 500 members.

\begin{tabular}{cccccc}
\hline Variable & $\mathbf{N}$ & Mean & Median & Stdev & ADF Test \\
\hline NCSKEW & 5246 & 0.1238 & 0.1024 & 1.0274 & $3264.73^{* * *}$ \\
DUVOL & 5246 & 0.0884 & 0.0796 & 0.7657 & $3349.95^{* * *}$ \\
ESG_SCORE & 5246 & 30.5249 & 27.6860 & 15.0895 & $1257.66^{* * *}$ \\
DTURNOVER & 5246 & -0.0046 & -0.0030 & 0.0252 & $3604.62^{* * *}$ \\
RET & 5246 & -0.0827 & -0.0570 & 0.4361 & $3884.29^{* * *}$ \\
PBR & 5246 & 6.3840 & 2.9571 & 36.0353 & $1292.50^{* * *}$ \\
SIZE & 5246 & 9.7038 & 9.5837 & 1.1518 & $1328.28^{* * *}$ \\
SIGMAR & 5246 & 0.0316 & 0.0274 & 0.0164 & $1894.72^{* * *}$ \\
LEV & 5246 & 21.2960 & 19.9755 & 15.0503 & $1657.01^{* * *}$ \\
ROA & 5246 & 0.0884 & 0.0767 & 0.0964 & $2110.71^{* * *}$ \\
ABACC & 5246 & 64.9508 & 0.0303 & 2881.001 & $3029.41^{* * *}$ \\
\hline
\end{tabular}

Note: NCSKEW is the negative coefficient of skewness of firm-specific weekly returns over the year. DUVOL is the natural logarithm of the ratio of the standard deviation of firm-specific weekly returns in the down weeks to the up weeks. ESG_SCORE is Bloomberg ESG disclosure score from the Bloomberg database. DTURNOVER is the detrended turnover. DTURNOVER is the average turnover over the current year minus the average turnover over the previous year, where turnover is the monthly trading volume divided by the total number of shares outstanding during the month. RET is the mean of firm-specific weekly returns during a given period times 100 PBR is the price per share divided by book value per share. SIZE is the natural logarithm of the market value of equity. SIGMAR is the standard deviation of firm-specific weekly returns. LEV is the total long-term debts divided by total assets. ROA is the profit before tax divided by total assets. ABACC is the absolute discretionary value of cash flow from operating activities minus net income, as estimated from the Jones model. Panel Augmented Dickey-Fuller (ADF) test was performed with a trend and an intercept. ${ }^{* * *}$ reports statistical significance at the $1 \%$ level.

Table 4. Descriptive statistics for Nikkei-225 members.

\begin{tabular}{cccccc}
\hline Variable & $\mathbf{N}$ & Mean & Median & Stdev & ADF Test \\
\hline NCSKEW & 2803 & 0.0597 & 0.0334 & 0.8880 & $1664.98^{* * *}$ \\
DUVOL & 2803 & 0.0376 & 0.0389 & 0.6958 & $1739.87^{* * *}$ \\
ESG_SCORE & 2803 & 36.9411 & 38.8430 & 11.4549 & $729.80^{* * *}$ \\
DTURNOVER & 2803 & -0.0021 & -0.0026 & 0.0864 & $1809.29^{* * *}$ \\
RET & 2803 & -0.1011 & -0.0850 & 0.4662 & $1903.46^{* * *}$ \\
PBR & 2803 & 1.6287 & 1.2433 & 1.5714 & $850.47^{* * *}$ \\
SIZE & 2803 & 13.4128 & 13.3618 & 1.1328 & $669.30^{* * *}$ \\
SIGMAR & 2803 & 0.0344 & 0.0317 & 0.0130 & $1122.43^{* * *}$ \\
LEV & 2803 & 18.4260 & 16.7496 & 13.9815 & $786.01^{* * *}$ \\
ROA & 2803 & 0.0505 & 0.0433 & 0.0572 & $908.06^{* * *}$ \\
ABACC & 2803 & 0.0291 & 0.0218 & 0.0277 & $1395.78^{* * *}$ \\
\hline
\end{tabular}

Note: NCSKEW is the negative coefficient of skewness of firm-specific weekly returns over the year. DUVOL is the natural logarithm of the ratio of the standard deviation of firm-specific weekly returns in the down weeks to the up weeks. ESG_SCORE is Bloomberg ESG disclosure score from the Bloomberg database. DTURNOVER is the detrended turnover. DTURNOVER is the average turnover over the current year minus the average turnover over the previous year, where turnover is the monthly trading volume divided by the total number of shares outstanding during the month. RET is the mean of firm-specific weekly returns during a given period times 100 PBR is the price per share divided by book value per share. SIZE is the natural logarithm of the market value of equity. SIGMAR is the standard deviation of firm-specific weekly returns. LEV is the total long-term debts divided by total assets. ROA is the profit before tax divided by total assets. ABACC is the absolute discretionary value of cash flow from operating activities minus net income, as estimated from the Jones model. Panel Augmented Dickey-Fuller (ADF) test was performed with a trend and an intercept. ${ }^{* * *}$ reports statistical significance at the $1 \%$ level.

\subsection{The Effect of ESG Disclosure on Crash Risk}

Table 5 compares the results of the regression analyses using a two-way fixed-effect model of the relationship between ESG disclosures and one-year-ahead firm-specific stock price crash risk. In this regression, we controlled for cross-section fixed effects and year fixed effects, as well as other potential determinants for crash risk. All reported standard errors and p-values were computed using the white period method. 
Table 5. Regression analysis on the effect of environmental, social, and governance disclosures on crash risk using static panel models.

\begin{tabular}{|c|c|c|c|c|c|c|}
\hline & \multicolumn{2}{|c|}{ Euro STOXX 600} & \multicolumn{2}{|c|}{ S\&P 500} & \multicolumn{2}{|c|}{ Nikkei-225 } \\
\hline & NCSKEW $W_{t}$ & $\mathrm{DUVOL}_{t}$ & NCSKEW $_{t}$ & DUVOL $_{t}$ & NCSKEW $_{t}$ & DUVOL $_{t}$ \\
\hline \multirow{2}{*}{$E S G \_S C O R E_{t-1}$} & -0.0007 & -0.0014 & 0.0014 & 0.0019 & -0.0001 & -0.0008 \\
\hline & $(0.0023)$ & $(0.0018)$ & 0.0029 & $(0.0021)$ & $(0.0047)$ & $(0.0034)$ \\
\hline \multirow{2}{*}{ DTURNOVER $R_{t-1}$} & -0.6138 & -0.4878 & -0.1584 & -0.1579 & 0.0389 & -0.0116 \\
\hline & $(0.4504)$ & $(0.3707)$ & $(0.9454)$ & $(0.6292)$ & $(0.3111)$ & $(0.2722)$ \\
\hline \multirow{2}{*}{$\mathrm{RET}_{t-1}$} & $0.0474 *$ & $0.0466^{* *}$ & $0.1433^{* * *}$ & $0.1458 * * *$ & $0.2316^{* * *}$ & $0.2281^{* * *}$ \\
\hline & $(0.0278)$ & $(0.0224)$ & $(0.0388)$ & $(0.0284)$ & $(0.0450)$ & $(0.0333)$ \\
\hline \multirow{2}{*}{$\mathrm{PBR}_{t-1}$} & $7.2 \times 10^{-5}$ & 0.0003 & $0.0007^{* * *}$ & $0.0007^{* * *}$ & 0.0376 & 0.0230 \\
\hline & $(0.0003)$ & $(0.0002)$ & $(0.0002)$ & $(0.0002)$ & $(0.0286)$ & $(0.0190)$ \\
\hline \multirow{2}{*}{$\mathrm{SIZE}_{t-1}$} & $0.5026^{* * *}$ & $0.4628^{* * *}$ & $0.6662^{* * *}$ & $0.5271^{* * *}$ & $0.4492^{* * *}$ & $0.4250^{* * *}$ \\
\hline & $(0.0452)$ & $(0.0349)$ & $(0.0509)$ & $(0.0385)$ & $(0.0817)$ & $(0.0602)$ \\
\hline \multirow{2}{*}{ SIGMAR $_{t-1}$} & $-5.6883^{* * *}$ & $-4.3256^{* * *}$ & -1.4930 & -0.8457 & -4.4931 & $-4.3903^{* *}$ \\
\hline & (1.4530) & $(1.0423)$ & $(1.5176)$ & (1.0118) & $(2.1677)$ & $(1.9019)$ \\
\hline \multirow{2}{*}{$\mathrm{LEV}_{t-1}$} & -0.0017 & -0.0016 & $-0.0055^{* *}$ & $-0.0041^{* *}$ & 0.0017 & 0.0011 \\
\hline & $(0.0025)$ & $(0.0020)$ & $(0.0023)$ & $(0.0017)$ & $(0.0047)$ & $(0.0035)$ \\
\hline \multirow{2}{*}{$R O A_{t-1}$} & -0.0527 & -0.0635 & -0.2577 & -0.0504 & 0.0211 & -0.2054 \\
\hline & $(0.0509)$ & $(0.0436)$ & $(0.3307)$ & $(0.2560)$ & $(0.7804)$ & $(0.5924)$ \\
\hline \multirow{2}{*}{$A B A C C_{t-1}$} & $0.0048^{* *}$ & $0.0053^{* * *}$ & $-2.5 \times 10^{-6 * * *}$ & $-4.3 \times 10^{-7}$ & -1.0253 & -0.7279 \\
\hline & $(0.0022)$ & $(0.0016)$ & $\left(5.6 \times 10^{-7}\right)$ & $\left(7.4 \times 10^{-7}\right)$ & $(0.7787)$ & $(0.5923)$ \\
\hline Sample (adjusted) & 2006-2019 & 2006-2019 & 2006-2019 & 2006-2019 & 2006-2019 & 2006-2019 \\
\hline Observations & 5495 & 5495 & 4985 & 4985 & 2590 & 2590 \\
\hline Adjusted $R^{2}$ & 0.0611 & 0.0391 & 0.0721 & 0.0897 & 0.0413 & 0.0575 \\
\hline $\begin{array}{c}\text { Cross-section fixed } \\
\text { effects }\end{array}$ & included & included & included & included & included & included \\
\hline Year fixed effects & included & included & included & included & included & included \\
\hline
\end{tabular}

Note: NCSKEW is the negative coefficient of skewness of firm-specific weekly returns over the year. DUVOL is the natural logarithm of the ratio of the standard deviation of firm-specific weekly returns in the down weeks to the up weeks. ESG_SCORE is Bloomberg ESG disclosure score from the Bloomberg database. DTURNOVER is the detrended turnover. DTURNOVER is the average turnover over the current year minus the average turnover over the previous year, where turnover is the monthly trading volume divided by the total number of shares outstanding during the month. RET is the mean of firm-specific weekly returns during a given period times 100 . PBR is the price per share divided by book value per share. SIZE is the natural logarithm of the market value of equity. SIGMAR is the standard deviation of firm-specific weekly returns. LEV is the total long-term debts divided by total assets. ROA is the profit before tax divided by total assets. ABACC is the absolute discretionary value of cash flow from operating activities minus net income, as estimated from the Jones model. Intercepts and dummies for each year are not shown. Standard errors, which are in parentheses, are robust to serial correlation. ${ }^{*}, * *$, and ${ }^{* * *}$ report statistical significance at the $10 \%, 5 \%$, and $1 \%$ levels, respectively. Variables definitions are compiled in the Appendices A and B.

Coefficients of environmental, social, and governance (ESG) disclosures were not statistically significant in the static model. ESG disclosures were not associated with oneyear-ahead stock price crash risk. The effects of ESG disclosures on crash risk were not observed in the two-way fixed-effects static model after controlling for other potential stock price crash determinants.

As expected, past returns (RETs), firm size (SIZE), and price-to-book ratio (PBR) were positively associated with future crash risk. Chen et al. (2001) found a positive relationship between RET and future crash risk. High past returns sustained in bubbles can decrease and fall back to fundamentals in prices. Chen et al. (2001) explained the reason for positive coefficients of SIZE as a difference in scope for discretionary disclosure between small and large firms. Although managers prefer to conceal bad news from market participants, the managers of smaller firms have more scope for disclosure timing. As expected, PBR was positively related to crash risk. The coefficients of stock volatility (SIGMAR) differed among analyses. In our opinion, the relationship between stock volatility and crash likelihood depends on the distribution.

Coefficients of financial leverage (LEV) were negative. A higher LEV indicates unstable management. Thus, we expected that higher LEV could lead to a crash in prices. The negative coefficients of LEV differed from our prediction. Statistically significant coefficients of the absolute discretionary value of cash flow from operating activities minus 
net income (ABACC) show both negative and positive signs. ABACC is considered as a proxy for levels of opacity in corporate financial reporting. We expected that a higher ABACC could lead to a future stock price crash. We must note that we employed the absolute discretionary value of cash flow from operating activities minus net income, not the absolute value of discretionary accruals.

We employed additional explanatory variables of lagged crash risk (NCSKEW or DUVOL) in the regression model, enabling us to analyze the relation between ESG disclosure and crash risk using dynamic models. Table 6 compares the results of regression analyses on the effect of environmental, social, and governance disclosure on crash risk in dynamic panel models. We performed these analyses using the dynamic GMM method, which can exclude other endogeneity biases. Things we require when using GMM are wide and short datasets and the stationarity of the series (Ahn and Schmidt 1995; Arellano and Bond 1991). All reported standard errors and p-values were computed using the white period method.

Table 6. Regression analysis on the effect of environmental, social, and governance disclosures on crash risk using dynamic panel models.

\begin{tabular}{|c|c|c|c|c|c|c|}
\hline & \multicolumn{2}{|c|}{ Euro STOXX 600} & \multicolumn{2}{|c|}{ S\&P 500} & \multicolumn{2}{|c|}{ Nikkei-225 } \\
\hline & NCSKEW $_{t}$ & $\mathrm{DUVOL}_{t}$ & NCSKEW $_{t}$ & $\operatorname{DUVOL}_{t}$ & $N_{C S K E W}$ & $D_{U V O L}$ \\
\hline$E S G \_S C O R E_{t-1}$ & $\begin{array}{l}-0.0235^{*} \\
(0.0124)\end{array}$ & $\begin{array}{l}-0.0181 \text { ** } \\
(0.0082)\end{array}$ & $\begin{array}{l}-0.0222 \\
(0.0158)\end{array}$ & $\begin{array}{l}-0.0129 \\
(0.0120)\end{array}$ & $\begin{array}{c}-0.0751^{* * *} \\
(0.0175)\end{array}$ & $\begin{aligned}- & 0.0405^{* * * *} \\
& (0.0137)\end{aligned}$ \\
\hline NCSKEW $W_{t-1}$ & $\begin{array}{l}0.0858^{* *} \\
(0.0419)\end{array}$ & & $\begin{array}{l}0.0851 * * \\
(0.0401)\end{array}$ & & $\begin{array}{c}0.0490 \\
(0.0368)\end{array}$ & \\
\hline$D U V O L_{t-1}$ & & $\begin{array}{c}0.0396 \\
(0.0556)\end{array}$ & & $\begin{array}{c}0.0416 \\
(0.0497)\end{array}$ & & $\begin{array}{l}0.1670 * * * \\
(0.0455)\end{array}$ \\
\hline DTURNOVER $R_{t-1}$ & $\begin{array}{c}0.8510 \\
(2.1352)\end{array}$ & $\begin{array}{l}-0.3289 \\
(1.5166)\end{array}$ & $\begin{array}{l}-0.3565 \\
(2.3539)\end{array}$ & $\begin{array}{l}3.9985 * * \\
(1.8951)\end{array}$ & $\begin{array}{c}0.5810 \\
(0.4326)\end{array}$ & $\begin{array}{l}0.5915 * \\
(0.3553)\end{array}$ \\
\hline $\mathrm{RET}_{t-1}$ & $\begin{array}{c}0.1941 \\
(0.1195)\end{array}$ & $\begin{array}{c}0.0556 \\
(0.1056)\end{array}$ & $\begin{array}{l}0.2821 * * \\
(0.1296)\end{array}$ & $\begin{array}{l}0.2298 * * \\
(0.1104)\end{array}$ & $\begin{array}{l}0.3165^{* * *} \\
(0.1104)\end{array}$ & $\begin{array}{l}0.4928^{* * *} \\
(0.1008)\end{array}$ \\
\hline $\mathrm{PBR}_{t-1}$ & $\begin{array}{c}0.0049 \\
(0.0052)\end{array}$ & $\begin{array}{c}0.0050 \\
(0.0053)\end{array}$ & $\begin{array}{c}0.0012 \\
(0.0027)\end{array}$ & $\begin{array}{l}-0.0008 \\
(0.0022)\end{array}$ & $\begin{array}{l}0.1420 * \\
(0.0741)\end{array}$ & $\begin{array}{l}0.0421 * * \\
(0.0606)\end{array}$ \\
\hline $\mathrm{SIZE}_{t-1}$ & $\begin{array}{c}0.8279 * * * \\
(0.1493)\end{array}$ & $\begin{array}{c}0.5612^{* * *} \\
(0.1138)\end{array}$ & $\begin{array}{l}0.6076^{* * *} \\
(0.2276)\end{array}$ & $\begin{array}{c}0.6867^{* * *} \\
(0.1772)\end{array}$ & $\begin{array}{l}0.3802 * \\
(0.2083)\end{array}$ & $\begin{array}{l}0.3408^{* *} \\
(0.1448)\end{array}$ \\
\hline $\operatorname{SIGMAR}_{t-1}$ & $\begin{array}{l}-3.3567 \\
(5.7344)\end{array}$ & $\begin{array}{l}-6.6139 \\
(4.0317)\end{array}$ & $\begin{array}{c}-13.2116^{* *} \\
(5.5819)\end{array}$ & $\begin{array}{l}-8.9440 * * \\
(4.5421)\end{array}$ & $\begin{array}{c}-15.3896^{* * *} \\
(5.4252)\end{array}$ & $\begin{array}{l}-8.1976^{* *} \\
(3.9800)\end{array}$ \\
\hline $\mathrm{LEV}_{t-1}$ & $\begin{array}{l}0.0224^{*} \\
(0.0120)\end{array}$ & $\begin{array}{c}0.0020 \\
(0.0090)\end{array}$ & $\begin{array}{l}-0.0010 \\
(0.0011)\end{array}$ & $\begin{array}{l}-0.0105 \\
(0.0085)\end{array}$ & $\begin{array}{l}0.0253 \text { * } \\
(0.0146)\end{array}$ & $\begin{array}{l}0.0427^{* * *} \\
(0.0108)\end{array}$ \\
\hline$R O A_{t-1}$ & $\begin{array}{l}-1.0736 \\
(0.8419)\end{array}$ & $\begin{array}{l}-0.0482 \\
(0.4573)\end{array}$ & $\begin{array}{c}0.1895 \\
(1.3612)\end{array}$ & $\begin{array}{l}-0.7039 \\
(0.9993)\end{array}$ & $\begin{array}{l}2.6724^{* *} \\
(1.3496)\end{array}$ & $\begin{array}{c}1.4209 \\
(1.1750)\end{array}$ \\
\hline$A B A C C_{t-1}$ & $\begin{array}{l}-0.0301 \\
(0.0465)\end{array}$ & $\begin{array}{l}-0.0263 \\
(0.0411)\end{array}$ & $\begin{array}{l}-0.0001 \\
(0.0001)\end{array}$ & $\begin{array}{c}-2.8 \times 10^{-6} \\
(0.0001)\end{array}$ & $\begin{array}{l}-0.9471 \\
(2.0197)\end{array}$ & $\begin{array}{l}-2.6365 \\
(1.9208)\end{array}$ \\
\hline $\begin{array}{c}\text { Sample (adjusted) } \\
\text { Observations }\end{array}$ & $\begin{array}{c}2007-2019 \\
4995\end{array}$ & $\begin{array}{l}2007-2019 \\
4995\end{array}$ & $\begin{array}{l}2007-2019 \\
4518\end{array}$ & $\begin{array}{c}2007-2019 \\
4518\end{array}$ & $\begin{array}{l}2007-2019 \\
2366\end{array}$ & $\begin{array}{c}2007-2019 \\
2366\end{array}$ \\
\hline $\begin{array}{l}\text { Cross-section fixed } \\
\text { effects }\end{array}$ & included & included & included & included & included & included \\
\hline Year fixed effects & included & included & included & included & included & included \\
\hline
\end{tabular}

Note: NCSKEW is the negative coefficient of skewness of firm-specific weekly returns over the year. DUVOL is the natural logarithm of the ratio of the standard deviation of firm-specific weekly returns in the down weeks to the up weeks. ESG_SCORE is Bloomberg ESG disclosure score from the Bloomberg database. DTURNOVER is the detrended turnover. DTURNOVER is the average turnover over the current year minus the average turnover over the previous year, where turnover is the monthly trading volume divided by the total number of shares outstanding during the month. RET is the mean of firm-specific weekly returns during a given period times 100 . PBR is the price per share divided by book value per share. SIZE is the natural logarithm of the market value of equity. SIGMAR is the standard deviation of firm-specific weekly returns. LEV is the total long-term debts divided by total assets. ROA is the profit before tax divided by total assets. ABACC is the absolute discretionary value of cash flow from operating activities minus net income, as estimated from the Jones model. Intercepts and dummies for each year are not shown. Standard errors, which are in parentheses, are robust to serial correlation. ${ }^{*}, * *$, and $^{* * *}$ report statistical significance at the $10 \%, 5 \%$, and $1 \%$ levels, respectively. 
As well as the results of analyses in the static model, coefficients of environmental, social, and governance (ESG) disclosures in the U.S. sample were not statistically significant in the dynamic model. On the other hand, coefficients of ESG disclosures in the European and Japanese market sample were statistically significant in the dynamic model. ESG disclosures were negatively associated with future stock price crash risk. The negative signs of NCSKEW and DUVOL were consistent with our prediction-that active firms regarding ESG disclosure are less likely to conceal bad news and, thus, are associated with lower crash risks. Our findings suggest that, when we avoid endogeneity bias, ESG disclosures can be used as stock price crash determinants in the European and Japanese markets.

Lagged crash risk (NCSKEW or DUVOL) was positively associated with one-yearahead crash risk, as expected. Stocks with higher crash risks were more likely to crash in the future. Coefficients of past returns (RETs), firm size (SIZE), stock volatility (SIGMAR), and price-to-book ratio (PBR) in Table 6 show the same signs as in Table 5. The coefficient of returns on assets (ROAs) was positive. While stocks with higher ROAs are attractive to investors, glamour stocks are more crash-prone. Detrended turnover (DTURNOVER) is a proxy for the level of disagreement among investors. Stocks with more different opinions in prices can lead to higher crash risk. The positive sign was consistent with our prediction. Coefficients of financial leverage (LEV) were positive in the dynamic model, as expected.

\subsection{ESG Disclosure Components}

The Bloomberg ESG database provides disclosure ratings for each factor of environmental, social, and governance scores. Thus, we performed analyses of the three ESG factors. Firm-level Bloomberg environmental disclosure score is written as E_SCORE in the analysis results. Firm-level Bloomberg social disclosure score is written as S_SCORE, and Firm-level Bloomberg governance disclosure score is written as G_SCORE. Regression analyses with the three ESG factors in place of ESG overall disclosure score were performed using the dynamic model with the GMM approach. We controlled for the same potential stock price crash determinants as in the other regression analyses. All reported standard errors and $p$-values in Section 4.3 were computed using the white period method.

Table 7 compares the results of regression analyses on the effect of environmental disclosure on crash risk in dynamic panel models. The coefficients of environmental disclosure were statistically significant for the Euro STOXX 600 and Nikkei-225 samples when DUVOL, as a proxy for crash risk, was employed. However, it was statistically insignificant for the S\&P 500 sample and for all samples when crash risk was proxied by NCSKEW.

Table 8 shows the results of the regression analyses on the effect of social disclosure on crash risk in dynamic panel models. Table 9 compares the results of the regression analyses on the effect of governance disclosure in dynamic panel models. Both social disclosure and governance disclosure were insignificant for the S\&P 500 sample, regardless of whether crash risks were proxied by NCSKEW or DUVOL. Meanwhile, social disclosure exhibited predictive power in the Nikkei-225 and Euro STOXX 600 samples only when NCSKEW was employed for the regression analysis. Governance disclosure was also statistically significant in the Euro STOXX 600 and Nikkei-225 samples only when crash risk was proxied by NCSKEW. 
Table 7. Regression analysis on the effect of environmental disclosure on crash risk using dynamic panel models.

\begin{tabular}{|c|c|c|c|c|c|c|}
\hline & \multicolumn{2}{|c|}{ Euro STOXX 600} & \multicolumn{2}{|c|}{ S\&P 500} & \multicolumn{2}{|c|}{ Nikkei-225 } \\
\hline & NCSKEW $W_{t}$ & DUVOL $_{t}$ & NCSKEW $_{t}$ & $D_{U V O L}$ & NCSKEW $_{t}$ & $\mathrm{DUVOL}_{t}$ \\
\hline$E_{-} S C O R E_{t-1}$ & $\begin{array}{l}-0.0120 \\
(0.0100)\end{array}$ & $\begin{array}{l}-0.0150 * * \\
(0.0072)\end{array}$ & $\begin{array}{c}0.0115 \\
(0.0110)\end{array}$ & $\begin{array}{c}0.0081 \\
(0.0090)\end{array}$ & $\begin{array}{l}-0.0143 \\
(0.0104)\end{array}$ & $\begin{array}{l}-0.0223 * * * \\
(0.0082)\end{array}$ \\
\hline NCSKEW $W_{t-1}$ & $\begin{array}{l}0.0806 \text { * } \\
(0.0442)\end{array}$ & & $\begin{array}{c}0.0577 \\
(0.0445)\end{array}$ & & $\begin{array}{l}0.0674^{*} \\
(0.0361)\end{array}$ & \\
\hline $\operatorname{DUVOL}_{t-1}$ & & $\begin{array}{c}0.0463 \\
(0.0576)\end{array}$ & & $\begin{array}{l}-0.0125 \\
(0.0510)\end{array}$ & & $\begin{array}{c}0.1717^{* * *} \\
(0.0465)\end{array}$ \\
\hline DTURNOVER $R_{t-1}$ & $\begin{array}{l}-0.6610 \\
(2.2136)\end{array}$ & $\begin{array}{l}-0.2384 \\
(1.4185)\end{array}$ & $\begin{array}{l}-1.4227 \\
(2.6334)\end{array}$ & $\begin{array}{c}3.0949 \\
(2.2847)\end{array}$ & $\begin{array}{l}-0.1810 \\
(0.5139)\end{array}$ & $\begin{array}{c}0.1299 \\
(0.3891)\end{array}$ \\
\hline $\mathrm{RET}_{t-1}$ & $\begin{array}{c}0.1743 \\
(0.1279)\end{array}$ & $\begin{array}{c}0.0405 \\
(0.1120)\end{array}$ & $\begin{array}{c}0.2040 \\
(0.1483)\end{array}$ & $\begin{array}{c}0.0812 \\
(0.1199)\end{array}$ & $\begin{array}{l}0.2691 * * \\
(0.1049)\end{array}$ & $\begin{array}{l}0.4981^{* * *} \\
(0.0965)\end{array}$ \\
\hline $\mathrm{PBR}_{t-1}$ & $\begin{array}{c}0.0036 \\
(0.0042)\end{array}$ & $\begin{array}{c}0.0020 \\
(0.0036)\end{array}$ & $\begin{array}{c}0.0003 \\
(0.0028)\end{array}$ & $\begin{array}{c}4.3 \times 10^{-5} \\
(0.0019)\end{array}$ & $\begin{array}{l}0.1551^{*} \\
(0.0818)\end{array}$ & $\begin{array}{c}0.0467 \\
(0.0608)\end{array}$ \\
\hline $\mathrm{SIZE}_{t-1}$ & $\begin{array}{c}0.8449^{* * *} \\
(0.1523)\end{array}$ & $\begin{array}{c}0.5260^{* * *} \\
(0.1091)\end{array}$ & $\begin{array}{c}0.9008^{* * *} \\
(0.2568)\end{array}$ & $\begin{array}{c}0.7177^{* * *} \\
(0.1826)\end{array}$ & $\begin{array}{c}-0.0481 \\
(0.1903)\end{array}$ & $\begin{array}{c}0.2212 \\
(0.1517)\end{array}$ \\
\hline SIGMAR $_{t-1}$ & $\begin{array}{c}1.1416 \\
(5.9548)\end{array}$ & $\begin{array}{c}-8.1819 * * \\
(4.0791)\end{array}$ & $\begin{array}{c}-10.5115 \\
(6.7566)\end{array}$ & $\begin{array}{l}-9.2521 \\
(4.8302)\end{array}$ & $\begin{array}{l}-5.8882 \\
(5.1898)\end{array}$ & $\begin{array}{l}-4.6786 \\
(3.8441)\end{array}$ \\
\hline $\mathrm{LEV}_{t-1}$ & $\begin{array}{c}0.0081 \\
(0.0118)\end{array}$ & $\begin{array}{l}-0.0030 \\
(0.0094)\end{array}$ & $\begin{array}{c}0.0049 \\
(0.0116)\end{array}$ & $\begin{array}{l}-0.0024 \\
(0.0087)\end{array}$ & $\begin{array}{l}0.0400^{* * *} \\
(0.0148)\end{array}$ & $\begin{array}{c}0.0407^{* * * *} \\
(0.0112)\end{array}$ \\
\hline$R O A_{t-1}$ & $\begin{array}{l}-1.6746 \\
(1.1232)\end{array}$ & $\begin{array}{c}-0.2823 \\
(0.4287)\end{array}$ & $\begin{array}{c}1.1722 \\
(1.1835)\end{array}$ & $\begin{array}{l}1.5010 * \\
(0.8960)\end{array}$ & $\begin{array}{c}3.9094^{* * *} \\
(1.3678)\end{array}$ & $\begin{array}{c}1.9044 \\
(1.1797)\end{array}$ \\
\hline$A B A C C_{t-1}$ & $\begin{array}{l}-0.0177 \\
(0.0371)\end{array}$ & $\begin{array}{l}-0.0073 \\
(0.0296)\end{array}$ & $\begin{array}{c}1.4 \times 10^{-5} \\
\left(7.0 \times 10^{-5}\right)\end{array}$ & $\begin{array}{c}7.2 \times 10^{-5} \\
\left(9.8 \times 10^{-5}\right)\end{array}$ & $\begin{array}{l}-0.5585 \\
(1.9107)\end{array}$ & $\begin{array}{c}-3.1413 * \\
(1.8745)\end{array}$ \\
\hline Sample (adjusted) & 2007-2019 & 2007-2019 & 2007-2019 & 2007-2019 & 2007-2019 & 2007-2019 \\
\hline Observations & 4637 & 4637 & 3386 & 3386 & 2259 & 2259 \\
\hline $\begin{array}{l}\text { Cross-section fixed } \\
\text { effects }\end{array}$ & included & included & included & included & included & included \\
\hline Year fixed effects & included & included & included & included & included & included \\
\hline
\end{tabular}

Note: NCSKEW is the negative coefficient of skewness of firm-specific weekly returns over the year. DUVOL is the natural logarithm of the ratio of the standard deviation of firm-specific weekly returns in the down weeks to the up weeks. E_SCORE is Bloomberg environmental disclosure score from the Bloomberg database. DTURNOVER is the detrended turnover. DTURNOVER is the average turnover over the current year minus the average turnover over the previous year, where turnover is the monthly trading volume divided by the total number of shares outstanding during the month. RET is the mean of firm-specific weekly returns during a given period times 100 . PBR is the price per share divided by book value per share. SIZE is the natural logarithm of the market value of equity. SIGMAR is the standard deviation of firm-specific weekly returns. LEV is the total long-term debts divided by total assets. ROA is the profit before tax divided by total assets. ABACC is the absolute discretionary value of cash flow from operating activities minus net income, as estimated from the Jones model. Intercepts and dummies for each year are not shown. Standard errors, which are in parentheses, are robust to serial correlation. * ***, and ${ }^{* * *}$ report statistical significance at the $10 \%, 5 \%$, and $1 \%$ levels, respectively.

Table 8. Regression analysis on the effect of social disclosure on crash risk using dynamic panel models.

\begin{tabular}{|c|c|c|c|c|c|c|}
\hline & \multicolumn{2}{|c|}{ Euro STOXX 600} & \multicolumn{2}{|c|}{ S\&P 500} & \multicolumn{2}{|c|}{ Nikkei-225 } \\
\hline & NCSKEW $_{t}$ & $D_{U V O L}$ & NCSKEW $_{t}$ & $\operatorname{DUVOL}_{t}$ & NCSKEW $W_{t}$ & $\operatorname{DUVOL}_{t}$ \\
\hline$S \_S C O R E_{t-1}$ & $\begin{array}{c}-0.0185^{*} \\
(0.0097)\end{array}$ & $\begin{array}{l}-0.0095 \\
(0.0078)\end{array}$ & $\begin{array}{l}-0.0142 \\
(0.0111)\end{array}$ & $\begin{array}{l}-0.0006 \\
(0.0093)\end{array}$ & $\begin{array}{c}-0.0476 \text { *** } \\
(0.0116)\end{array}$ & $\begin{array}{c}-0.0221 \text { ** } \\
(0.0103)\end{array}$ \\
\hline $\operatorname{NCSKEW}_{t-1}$ & $\begin{array}{l}0.0790 * \\
(0.0443)\end{array}$ & & $\begin{array}{c}0.0654 \\
(0.0424)\end{array}$ & & $\begin{array}{l}0.0840 \text { ** } \\
(0.0386)\end{array}$ & \\
\hline$D U V O L_{t-1}$ & & $\begin{array}{c}0.0870 \\
(0.0552)\end{array}$ & & $\begin{array}{c}0.0346 \\
(0.0498)\end{array}$ & & $\begin{array}{c}0.2025^{* * *} \\
(0.0480)\end{array}$ \\
\hline DTURNOVER $R_{t-1}$ & $\begin{array}{l}-0.9564 \\
(2.1919)\end{array}$ & $\begin{array}{l}-2.2282 \\
(1.5322)\end{array}$ & $\begin{array}{c}0.2341 \\
(2.3126)\end{array}$ & $\begin{array}{l}4.3457 * * \\
(1.7851)\end{array}$ & $\begin{array}{l}0.8022 * \\
(0.4845)\end{array}$ & $\begin{array}{c}0.5229 \\
(0.3431)\end{array}$ \\
\hline
\end{tabular}


Table 8. Cont

\begin{tabular}{|c|c|c|c|c|c|c|}
\hline & \multicolumn{2}{|c|}{ Euro STOXX 600} & \multicolumn{2}{|c|}{ S\&P 500} & \multicolumn{2}{|c|}{ Nikkei-225 } \\
\hline & $N C S K E W_{t}$ & $D_{U V O L}$ & $N_{C S K E W_{t}}$ & $D_{U V O L}$ & NCSKEW $W_{t}$ & $D_{U V O L}$ \\
\hline \multirow{2}{*}{$\mathrm{RET}_{t-1}$} & 0.1748 & 0.1347 & $0.2378 *$ & $0.2215 *$ & $0.3152 * * *$ & $0.5122 * * *$ \\
\hline & $(0.1271)$ & $(0.1055)$ & $(0.1401)$ & $(0.1160)$ & $(0.1144)$ & $(0.0998)$ \\
\hline \multirow{2}{*}{$\mathrm{PBR}_{t-1}$} & 0.0036 & 0.0040 & 0.0011 & -0.0006 & $0.2442^{* * *}$ & 0.0783 \\
\hline & $(0.0042)$ & $(0.0045)$ & $(0.0028)$ & $(0.0021)$ & $(0.0821)$ & $(0.0573)$ \\
\hline \multirow{2}{*}{$\mathrm{SIZE}_{t-1}$} & $1.0150^{* * *}$ & $0.5689^{* * *}$ & $0.6787^{* *}$ & $0.6190^{* * *}$ & 0.2291 & 0.2623 * \\
\hline & $(0.1786)$ & $(0.1237)$ & $(0.2653)$ & $(0.1867)$ & $(0.2085)$ & $(0.1390)$ \\
\hline \multirow{2}{*}{$\mathrm{SIGMAR}_{t-1}$} & 2.0931 & -6.1765 & -12.2037 * & -8.7059 * & $-12.5299^{* *}$ & -5.2958 \\
\hline & (5.9064) & $(4.0607)$ & (6.2918) & $(4.6932)$ & $(5.4106)$ & $(3.9486)$ \\
\hline \multirow{2}{*}{$\mathrm{LEV}_{t-1}$} & -0.0120 & 0.0014 & 0.0030 & -0.0082 & $0.0360^{* * *}$ & $0.0417^{* * *}$ \\
\hline & $(0.0129)$ & $(0.0093)$ & $(0.0115)$ & $(0.0084)$ & $(0.0134)$ & $(0.0108)$ \\
\hline \multirow{2}{*}{$R O A_{t-1}$} & -1.9263 & -0.3404 & 0.0108 & 0.1515 & $2.9410 * *$ & 1.5210 \\
\hline & $(1.2163)$ & $(0.4881)$ & $(1.4471)$ & $(0.9922)$ & $(1.4581)$ & $(1.1832)$ \\
\hline \multirow{2}{*}{$A B A C C_{t-1}$} & -0.0012 & 0.0038 & $-6.2 \times 10^{-5}$ & $1.5 \times 10^{-5}$ & 0.2572 & -1.3096 \\
\hline & $(0.0360)$ & $(0.0267)$ & $(0.0001)$ & $(0.0001)$ & $(2.0894)$ & $(1.8997)$ \\
\hline Sample (adjusted) & 2007-2019 & 2007-2019 & 2007-2019 & 2007-2019 & 2007-2019 & 2007-2019 \\
\hline Observations & 4844 & 4844 & 4369 & 4369 & 2356 & 2356 \\
\hline $\begin{array}{l}\text { Cross-section fixed } \\
\text { effects }\end{array}$ & included & included & included & included & included & included \\
\hline Year fixed effects & included & included & included & included & included & included \\
\hline
\end{tabular}

Note: NCSKEW is the negative coefficient of skewness of firm-specific weekly returns over the year. DUVOL is the natural logarithm of the ratio of the standard deviation of firm-specific weekly returns in the down weeks to the up weeks. S_SCORE is Bloomberg social disclosure score from the Bloomberg database. DTURNOVER is the detrended turnover. DTURNOVER is the average turnover over the current year minus the average turnover over the previous year, where turnover is the monthly trading volume divided by the total number of shares outstanding during the month. RET is the mean of firm-specific weekly returns during a given period times 100 . PBR is the price per share divided by book value per share. SIZE is the natural logarithm of the market value of equity. SIGMAR is the standard deviation of firm-specific weekly returns. LEV is the total long-term debts divided by total assets. ROA is the profit before tax divided by total assets. ABACC is the absolute discretionary value of cash flow from operating activities minus net income, as estimated from the Jones model. Intercepts and dummies for each year are not shown. Standard errors, which are in parentheses, are robust to serial correlation. ${ }^{* *}$, and ${ }^{* * *}$ report statistical significance at the $10 \%, 5 \%$, and $1 \%$ levels, respectively.

As well as ESG overall disclosure, the three ESG factors were not associated with crash risk in the S\&P 500 sample. While the coefficients of ESG overall disclosure were negative and statistically significant in the dynamic model, a few coefficients of the three ESG factors were significant in the sample of the Euro STOXX 600. These results suggest that the combination of environmental, social, and governance factors produced the observed predictive power in the European region. On the other hand, the three ESG factors were significant and associated with crash risk (NCSKEW or DUVOL) in more analyses of the Nikkei-225 sample. In particular, the coefficients of social disclosure were significant, regardless of the proxy used for crash risk. However, as well as the European region, these results suggest that the combination of environmental, social, and governance factors produced the observed predictive power in Japan. 
Table 9. Regression analysis on the effect of governance disclosure on crash risk using dynamic panel models.

\begin{tabular}{|c|c|c|c|c|c|c|}
\hline & \multicolumn{2}{|c|}{ Euro STOXX 600} & \multicolumn{2}{|c|}{ S\&P 500} & \multicolumn{2}{|c|}{ Nikkei-225 } \\
\hline & NCSKEW $_{t}$ & DUVOL $_{t}$ & NCSKEW $_{t}$ & $\operatorname{DUVOL}_{t}$ & NCSKEW $_{t}$ & DUVOL $_{t}$ \\
\hline$G_{-} S C O R E_{t-1}$ & $\begin{array}{l}-0.0229^{*} \\
(0.0121)\end{array}$ & $\begin{array}{l}-0.0015 \\
(0.0088)\end{array}$ & $\begin{array}{l}-0.0302 \\
(0.0263)\end{array}$ & $\begin{array}{l}-0.0225 \\
(0.0190)\end{array}$ & $\begin{array}{c}-0.0509 * * * \\
(0.0156)\end{array}$ & $\begin{array}{l}-0.0133 \\
(0.0115)\end{array}$ \\
\hline$N_{C S K E W}$ & $\begin{array}{l}0.1083 * * \\
(0.0425)\end{array}$ & & $\begin{array}{l}0.0721 * \\
(0.0405)\end{array}$ & & $\begin{array}{l}0.0675 * \\
(0.0358)\end{array}$ & \\
\hline$D U V O L_{t-1}$ & & $\begin{array}{l}0.1002 * \\
(0.0553)\end{array}$ & & $\begin{array}{c}0.0587 \\
(0.0500)\end{array}$ & & $\begin{array}{c}0.1902^{* * *} \\
(0.0481)\end{array}$ \\
\hline DTURNOVER $R_{t-1}$ & $\begin{array}{c}0.9934 \\
(2.4402)\end{array}$ & $\begin{array}{l}-1.0105 \\
(1.6707)\end{array}$ & $\begin{array}{c}0.1251 \\
(2.3201)\end{array}$ & $\begin{array}{l}4.7074 * * \\
(1.8475)\end{array}$ & $\begin{array}{c}0.3416 \\
(0.4319)\end{array}$ & $\begin{array}{c}0.4568 \\
(0.3552)\end{array}$ \\
\hline $\mathrm{RET}_{t-1}$ & $\begin{array}{l}0.2767^{* *} \\
(0.1213)\end{array}$ & $\begin{array}{l}0.1825 * \\
0.1077)\end{array}$ & $\begin{array}{l}0.2516^{*} \\
(0.1290)\end{array}$ & $\begin{array}{l}0.2780 * * \\
(0.1112)\end{array}$ & $\begin{array}{l}0.3512 * * * \\
(0.1054)\end{array}$ & $\begin{array}{l}0.5450 * * * \\
(0.1003)\end{array}$ \\
\hline $\mathrm{PBR}_{t-1}$ & $\begin{array}{c}0.0049 \\
(0.0053)\end{array}$ & $\begin{array}{c}0.0035 \\
(0.0044)\end{array}$ & $\begin{array}{c}0.0019 \\
(0.0029)\end{array}$ & $\begin{array}{l}-0.0004 \\
(0.0021)\end{array}$ & $\begin{array}{c}0.0848 \\
(0.0682)\end{array}$ & $\begin{array}{c}0.0075 \\
(0.0553)\end{array}$ \\
\hline $\mathrm{SIZE}_{t-1}$ & $\begin{array}{l}0.9084^{* * *} \\
(0.1696)\end{array}$ & $\begin{array}{c}0.5730^{* * *} \\
(0.1231)\end{array}$ & $\begin{array}{l}0.7218^{* * *} \\
(0.2350)\end{array}$ & $\begin{array}{l}0.6544^{* * *} \\
(0.1835)\end{array}$ & $\begin{array}{c}0.3052 \\
(0.1906)\end{array}$ & $\begin{array}{l}0.3012 * * \\
(0.1328)\end{array}$ \\
\hline SIGMAR $_{t-1}$ & $\begin{array}{l}-6.2070 \\
(5.9598)\end{array}$ & $\begin{array}{l}-9.5328 * * \\
(3.9820)\end{array}$ & $\begin{array}{c}-10.3934 \\
(5.0131)\end{array}$ & $\begin{array}{c}-9.7495^{* *} \\
(4.4102)\end{array}$ & $\begin{array}{l}-8.3772 * \\
(4.8208)\end{array}$ & $\begin{array}{l}-5.8335 \\
(3.9218)\end{array}$ \\
\hline $\mathrm{LEV}_{t-1}$ & $\begin{array}{l}0.0267 * * \\
(0.0119)\end{array}$ & $\begin{array}{l}-0.0008 \\
(0.0092)\end{array}$ & $\begin{array}{l}-0.0041 \\
(0.0118)\end{array}$ & $\begin{array}{l}-0.0112 \\
(0.0091)\end{array}$ & $\begin{array}{l}0.0290 * * \\
(0.0137)\end{array}$ & $\begin{array}{c}0.0414^{* * *} \\
(0.0106)\end{array}$ \\
\hline$R O A_{t-1}$ & $\begin{array}{l}-1.1616 \\
(0.8720)\end{array}$ & $\begin{array}{l}-0.6752 \\
(0.6097)\end{array}$ & $\begin{array}{l}-0.2347 \\
(1.4325)\end{array}$ & $\begin{array}{c}0.5990 \\
(1.0489)\end{array}$ & $\begin{array}{l}3.7894^{* * *} \\
(1.2854)\end{array}$ & $\begin{array}{l}2.0800^{*} \\
(1.1459)\end{array}$ \\
\hline$A B A C C_{t-1}$ & $\begin{array}{l}4.0000 * * \\
(1.7805)\end{array}$ & $\begin{array}{l}4.3946^{* * *} \\
(1.5900)\end{array}$ & $\begin{array}{c}-9.9 \times 10^{-5} \\
(0.0001)\end{array}$ & $\begin{array}{c}-6.5 \times 10^{-5} \\
(0.0001)\end{array}$ & $\begin{array}{c}1.4924 \\
(2.0103)\end{array}$ & $\begin{array}{l}-1.1884 \\
(1.8895)\end{array}$ \\
\hline $\begin{array}{c}\text { Sample (adjusted) } \\
\text { Observations }\end{array}$ & $\begin{array}{c}2007-2019 \\
4994\end{array}$ & $\begin{array}{c}2007-2019 \\
4994\end{array}$ & $\begin{array}{c}2007-2019 \\
4518\end{array}$ & $\begin{array}{c}2007-2019 \\
4518\end{array}$ & $\begin{array}{c}2007-2019 \\
2364\end{array}$ & $\begin{array}{c}2007-2019 \\
2364\end{array}$ \\
\hline $\begin{array}{c}\text { Cross-section fixed } \\
\text { effects }\end{array}$ & included & included & included & included & included & included \\
\hline Year fixed effects & included & included & included & included & included & included \\
\hline
\end{tabular}

Note: NCSKEW is the negative coefficient of skewness of firm-specific weekly returns over the year. DUVOL is the natural logarithm of the ratio of the standard deviation of firm-specific weekly returns in the down weeks to the up weeks. G_SCORE is Bloomberg governance disclosure score from the Bloomberg database. DTURNOVER is the detrended turnover. DTURNOVER is the average turnover over the current year minus the average turnover over the previous year, where turnover is the monthly trading volume divided by the total number of shares outstanding during the month. RET is the mean of firm-specific weekly returns during a given period times 100 . PBR is the price per share divided by book value per share. SIZE is the natural logarithm of the market value of equity. SIGMAR is the standard deviation of firm-specific weekly returns. LEV is the total long-term debts divided by total assets. ROA is the profit before tax divided by total assets. ABACC is the absolute discretionary value of cash flow from operating activities minus net income, as estimated from the Jones model. Intercepts and dummies for each year are not shown. Standard errors, which are in parentheses, are robust to serial correlation. * **, and ${ }^{* * *}$ report statistical significance at the $10 \%, 5 \%$, and $1 \%$ levels, respectively.

\section{Conclusions}

Stock price crashes are a common concern among market participants. In this study, we investigated how environmental, social, and governance (ESG) disclosures are associated with future stock price crash risks in three regions: Europe, the United States, and Japan. Bad news hoarding theory (Jin and Myers 2006) explains that information asymmetry between inside corporate managers and outside investors leads to stock price crashes. Several researchers have, then, argued that socially responsible firms are more likely to be ethical in information supply and avoid bad news hoarding behavior, leading to lower stock price crash risks. On the other hand, there exists concerns that nonethical firms may disguise bad information from stakeholders with corporate socially responsible behaviors.

This study considered ESG disclosure as a proxy for corporate ethical behavior and tendency toward information supply. We would expect that more active firms, regarding ESG disclosure, are more likely to provide transparent information, leading to lower future stock price crashes. To investigate the relationship between ESG disclosure and stock price crash risk in three regions, we employed major market index components in each region as samples: the Euro STOXX 600 for Europe, the S\&P 500 for the United States, and the Nikkei-225 for Japan. 
We performed regression analyses on the effects of ESG disclosure on one-year-ahead stock price crash risks after controlling for detrended turnover, past return, price-to-book ratio, firm size, stock volatility financial leverage, returns on assets, and the absolute discretionary value of cash flow from operating activities minus net income. Researchers have found these control variables to be potential stock price crash determinants in studies. We also controlled for cross-section fixed effects and time fixed effects.

We found that the ESG disclosure coefficients were not statistically significant when using the static model. We also performed regression analyses using dynamic models (through the GMM approach), in order to mitigate potential endogeneity bias. In the dynamic models, ESG disclosure coefficients were significant and negative in the Euro STOXX 600 and Nikkei-225 samples. On the other hand, they were not significant in the S\&P 500 sample. Our findings suggest that ESG disclosure can decrease stock price crash likelihood in Europe and Japan after controlling for endogeneity. On the other hand, ESG disclosure did not exhibit predictive power for stock price crash in the United States.

Our findings suggest that the significance of stock market determinants depends on the region. Stock markets in different regions differ in their characteristics. There are many of the world largest firms in the United States. According to the Global Sustainable Investment Alliance (2018), Europe and the United States had about USD 14,075 billion and about USD 11,995 billion of sustainable investment assets, respectively. The sustainable investing assets managed by these two regions accounted for more than $80 \%$ of the global sustainable investing assets. On the other hand, the proportion of sustainable investment (relative to total managed assets) showed a significant difference: $48.8 \%$ for Europe and $25.7 \%$ for the United States. There is a possibility that these differences in market characteristics produced the different results in the sample for the United States.

The mean of the firm-level ESG disclosure score for the S\&P 500 was the lowest among the three market indexes. The different rating agencies employ different methodologies. Academics and institutions have argued the transparency and reliability of ESG ratings provided by rating agencies. Yuyama et al. (2019) found no significant relationship between ESG disclosures and investment returns in the Japanese stock market. Arribas et al. (2019) found no significant difference between socially responsible investments and conventional ones in the United States. Although socially responsible firms would show good performance in theory, some findings were consistent with the criticism of methodologies employed by rating agencies. There is a possibility that market participants do not consider firm-level ESG disclosures in the United States, as findings in this study suggest. ESG disclosure lowers future stock price crash risk; however, the effect and predictive power of ESG disclosure differ among regions.

There are some points that we must note: first, we chose major market index components as a sample to represent stock markets and economies, for comparison among regions. Our empirical results may reflect the market situations. The listed firms on the major market indexes tend to be large and a future research topic will be whether small firms benefit from ESG disclosures. Furthermore, the stock markets may differ depending upon the maturity of the market. It will be an issue for future studies to apply a similar methodology to other markets in developing countries. Second, the ESG scores provided by different rating providers are different. Kim et al. (2014) found that CSR performance coefficients (MSCI ESG) were significant in a sample of U.S. firms. Although ESG disclosure differs from its performance, the two can be confused.

Author Contributions: Formal analysis, R.M.; investigation, R.M.; data curation, R.M.; writingoriginal draft preparation, R.M.; writing-review and editing, S.H.; supervision, S.H.; funding acquisition, S.H. All authors have read and agreed to the published version of the manuscript.

Funding: This work was supported by JSPS KAKENHI Grant Number 17 H00983.

Data Availability Statement: The data source of our study is Bloomberg.

Acknowledgments: We are grateful to two anonymous reviewers for their helpful comments and suggestions. 
Conflicts of Interest: The authors declare no conflict of interest.

\section{Appendix A. Variables Definitions}

1. Crash risk variables NCSKEW is the negative coefficient of skewness of firm-specific weekly returns over the year. DUVOL is the down-to-up volatility, calculated as the natural logarithm of the ratio of the standard deviation of firm-specific weekly returns in down weeks to those in up weeks. Firm-specific return is defined as the natural logarithm of one plus the residual from the following regression model:

$$
r_{j, \tau}=\alpha_{j}+\beta_{1 . j} r_{m, \tau-2}+\beta_{2 . j} r_{m, \tau-1}+\beta_{3 . j} r_{m, \tau}+\beta_{4 . j} r_{m, \tau+1}+\beta_{5 . j} r_{m, \tau+2}+\varepsilon_{j, \tau} .
$$

2. ESG variables ESG_SCORE is the Bloomberg ESG disclosure score from the Bloomberg database. E_SCORE is the Bloomberg environmental disclosure score from the Bloomberg database. S_SCORE is the Bloomberg social disclosure score from the Bloomberg database. G_SCORE is the Bloomberg governance disclosure score from the Bloomberg database.

3. Control variables DTURNOVER is the detrended turnover, calculated as the average turnover over the current year minus the average turnover over the previous year; turnover is calculated as the monthly trading volume divided by the total number of shares outstanding during the month. RET is past returns calculated as the mean of firm-specific weekly returns during a given period times 100. PBR is the price-to-book ratio, defined as the price per share divided by book value per share. SIZE is the firm size, calculated as the natural logarithm of the market value of equity. SIGMAR is the stock volatility, calculated as the standard deviation of firm-specific weekly returns. LEV is the financial leverage, calculated as total long-term debts divided by total assets. ROA is the returns on assets, calculated as profit before tax divided by total assets. ABACC is the absolute discretionary value of cash flow from operating activities minus net income, as estimated from the Jones model.

Appendix B. Correlation Matrix

Table A1. Correlation matrix for Euro STOXX 600 members.

\begin{tabular}{|c|c|c|c|c|c|c|c|c|c|c|c|c|}
\hline Variable & & A & B & $\mathrm{C}$ & D & $\mathrm{E}$ & F & G & $\mathbf{H}$ & I & $\mathbf{J}$ & $\mathbf{K}$ \\
\hline NCSKEW & A & 1.00 & & & & & & & & & & \\
\hline DUVOL & B & 0.92 & 1.00 & & & & & & & & & \\
\hline ESG_SCORE & $\mathrm{C}$ & 0.04 & 0.03 & 1.00 & & & & & & & & \\
\hline DTURNOVER & $\mathrm{D}$ & 0.12 & 0.13 & -0.03 & 1.00 & & & & & & & \\
\hline RET & $\mathrm{E}$ & -0.60 & -0.72 & 0.01 & -0.02 & 1.00 & & & & & & \\
\hline PBR & $\mathrm{F}$ & -0.03 & -0.03 & -0.02 & -0.00 & 0.02 & 1.00 & & & & & \\
\hline SIZE & G & -0.00 & -0.01 & 0.47 & 0.00 & 0.09 & -0.01 & 1.00 & & & & \\
\hline SIGMAR & $\mathrm{H}$ & 0.11 & 0.07 & -0.19 & 0.07 & -0.14 & -0.02 & -0.30 & 1.00 & & & \\
\hline LEV & I & 0.02 & 0.03 & 0.08 & -0.01 & -0.01 & 0.03 & -0.02 & -0.02 & 1.00 & & \\
\hline $\mathrm{ROA}$ & $\mathrm{J}$ & -0.03 & -0.03 & -0.09 & 0.01 & 0.04 & 0.24 & -0.00 & -0.05 & -0.12 & 1.00 & \\
\hline ABACC & $\mathrm{K}$ & -0.01 & -0.02 & -0.02 & 0.05 & 0.04 & -0.00 & -0.02 & 0.07 & 0.03 & -0.00 & 1.00 \\
\hline
\end{tabular}

Note: NCSKEW is the negative coefficient of skewness of firm-specific weekly returns over the year. DUVOL is the natural logarithm of the ratio of the standard deviation of firm-specific weekly returns in the down weeks to the up weeks. ESG_SCORE is Bloomberg ESG disclosure score from the Bloomberg database. DTURNOVER is the detrended turnover. DTURNOVER is the average turnover over the current year minus the average turnover over the previous year, where turnover is the monthly trading volume divided by the total number of shares outstanding during the month. RET is the mean of firm-specific weekly returns during a given period times 100 . PBR is the price per share divided by book value per share. SIZE is the natural logarithm of the market value of equity. SIGMAR is the standard deviation of firm-specific weekly returns. LEV is the total long-term debts divided by total assets. ROA is the profit before tax divided by total assets. $\mathrm{ABACC}$ is the absolute discretionary value of cash flow from operating activities minus net income, as estimated from the Jones model. 
Table A2. Correlation Matrix for S\&P 500 members.

\begin{tabular}{|c|c|c|c|c|c|c|c|c|c|c|c|c|}
\hline Variable & & A & B & $\mathrm{C}$ & D & $\mathrm{E}$ & F & G & $\mathbf{H}$ & I & $\mathbf{J}$ & $\mathbf{K}$ \\
\hline NCSKEW & $\mathrm{A}$ & 1.00 & & & & & & & & & & \\
\hline DUVOL & B & 0.92 & 1.00 & & & & & & & & & \\
\hline ESG_SCORE & $\mathrm{C}$ & 0.05 & 0.06 & 1.00 & & & & & & & & \\
\hline DTURNOVER & $\mathrm{D}$ & 0.08 & 0.09 & 0.06 & 1.00 & & & & & & & \\
\hline RET & $\mathrm{E}$ & -0.61 & -0.72 & -0.03 & -0.10 & 1.00 & & & & & & \\
\hline PBR & $\mathrm{F}$ & -0.02 & -0.02 & 0.01 & 0.02 & 0.02 & 1.00 & & & & & \\
\hline SIZE & G & -0.01 & -0.00 & 0.49 & 0.04 & 0.04 & 0.05 & 1.00 & & & & \\
\hline SIGMAR & $\mathrm{H}$ & 0.04 & 0.01 & -0.18 & 0.12 & -0.11 & -0.02 & -0.32 & 1.00 & & & \\
\hline LEV & I & 0.02 & 0.03 & 0.12 & 0.07 & -0.03 & 0.12 & -0.02 & -0.01 & 1.00 & & \\
\hline $\mathrm{ROA}$ & $\mathrm{J}$ & -0.02 & -0.03 & -0.01 & -0.03 & 0.09 & 0.09 & 0.14 & -0.17 & -0.19 & 1.00 & \\
\hline ABACC & $\mathrm{K}$ & -0.00 & -0.01 & 0.02 & 0.01 & 0.02 & -0.00 & 0.00 & 0.02 & 0.00 & 0.01 & 1.00 \\
\hline
\end{tabular}

Note: NCSKEW is the negative coefficient of skewness of firm-specific weekly returns over the year. DUVOL is the natural logarithm of the ratio of the standard deviation of firm-specific weekly returns in the down weeks to the up weeks. ESG_SCORE is Bloomberg ESG disclosure score from the Bloomberg database. DTURNOVER is the detrended turnover. DTURNOVER is the average turnover over the current year minus the average turnover over the previous year, where turnover is the monthly trading volume divided by the total number of shares outstanding during the month. RET is the mean of firm-specific weekly returns during a given period times 100 . PBR is the price per share divided by book value per share. SIZE is the natural logarithm of the market value of equity. SIGMAR is the standard deviation of firm-specific weekly returns. LEV is the total long-term debts divided by total assets. ROA is the profit before tax divided by total assets. ABACC is the absolute discretionary value of cash flow from operating activities minus net income, as estimated from the Jones model.

Table A3. Correlation Matrix for Nikkei-225 members.

\begin{tabular}{|c|c|c|c|c|c|c|c|c|c|c|c|c|}
\hline Variable & & A & B & C & D & E & $\mathbf{F}$ & G & $\mathbf{H}$ & I & $\mathbf{J}$ & $\mathbf{K}$ \\
\hline NCSKEW & $\mathrm{A}$ & 1.00 & & & & & & & & & & \\
\hline DUVOL & B & 0.92 & 1.00 & & & & & & & & & \\
\hline ESG_SCORE & C & 0.04 & 0.03 & 1.00 & & & & & & & & \\
\hline DTURNOVER & $\mathrm{D}$ & 0.00 & -0.02 & -0.02 & 1.00 & & & & & & & \\
\hline RET & $\mathrm{E}$ & -0.60 & -0.72 & 0.06 & 0.04 & 1.00 & & & & & & \\
\hline PBR & $\mathrm{F}$ & -0.11 & -0.13 & -0.24 & 0.01 & 0.16 & 1.00 & & & & & \\
\hline SIZE & G & 0.03 & 0.02 & 0.22 & -0.01 & 0.02 & 0.10 & 1.00 & & & & \\
\hline SIGMAR & $\mathrm{H}$ & 0.01 & -0.02 & -0.26 & 0.29 & -0.09 & 0.15 & -0.28 & 1.00 & & & \\
\hline LEV & I & -0.03 & -0.03 & -0.02 & -0.02 & -0.00 & -0.11 & -0.06 & 0.03 & 1.00 & & \\
\hline ROA & $\mathrm{J}$ & 0.07 & 0.08 & -0.11 & -0.00 & -0.06 & 0.49 & 0.22 & 0.04 & -0.32 & 1.00 & \\
\hline ABACC & $\mathrm{K}$ & -0.02 & -0.03 & -0.15 & 0.03 & 0.04 & 0.15 & -0.04 & 0.17 & 0.01 & -0.03 & 1.00 \\
\hline
\end{tabular}

Note: NCSKEW is the negative coefficient of skewness of firm-specific weekly returns over the year. DUVOL is the natural logarithm of the ratio of the standard deviation of firm-specific weekly returns in the down weeks to the up weeks. ESG_SCORE is Bloomberg ESG disclosure score from the Bloomberg database. DTURNOVER is the detrended turnover. DTURNOVER is the average turnover over the current year minus the average turnover over the previous year, where turnover is the monthly trading volume divided by the total number of shares outstanding during the month. RET is the mean of firm-specific weekly returns during a given period times 100 . PBR is the price per share divided by book value per share. SIZE is the natural logarithm of the market value of equity. SIGMAR is the standard deviation of firm-specific weekly returns. LEV is the total long-term debts divided by total assets. ROA is the profit before tax divided by total assets. ABACC is the absolute discretionary value of cash flow from operating activities minus net income, as estimated from the Jones model.

\section{References}

Ahn, Seung C., and Peter Schmidt. 1995. Efficient estimation of models for dynamic panel data. Journal of Econometrics 68: 5-27. [CrossRef]

Arellano, Manuel, and Stephen Bond. 1991. Some tests of specification for panel data: Monte Carlo evidence and an application to employment equations. The Review of Economic Studies 58: 277-97. [CrossRef]

Arribas, Iván, María Dolores Espinós-Vañó, Fernando García, and Paula Beatriz Morales-Bañuelos. 2019. The Inclusion of Socially Irresponsible Companies in Sustainable Stock Indices. Sustainability 11: 2047. [CrossRef]

Bloomberg Professional Services. 2020. Environmental, Social and Governance (ESG) Data: Content and Data. Available online: https:/ / www.bloomberg.com/professional/solution/esg/ (accessed on 28 December 2020).

Bloomberg Professional Services. n.d.a. Nikkei 225. Available online: https:/ / www.bloomberg.com/quote/NKY:IND (accessed on 28 December 2020).

Bloomberg Professional Services. n.d.b. S\&P 500 INDEX. Available online: https:/ / www.bloomberg.com/quote/SPX:IND (accessed on 28 December 2020). 
Boffo, R., and R. Patalano. 2020. ESG Investing: Practices, Progress and Challenges. Paris: OECD, Available online: www.oecd.org/ finance/ESG-Investing-Practices-Progress-and-Challenges.pdf (accessed on 28 December 2020).

Chen, Joseph, Harrison Hong, and Jeremy C. Stein. 2001. Forecasting crashes: Trading volume, past returns, and conditional skewness in stock prices. Journal of Financial Economics 61: 345-81. [CrossRef]

Chidi, Hilary. 2018. A Comparative Analysis of Socially Responsible Investment (SRI) Funds: How Sustainable Are SRI Funds? Master's dissertation, Harvard Extension School, Cambridge, MA, USA. Available online: http://nrs.harvard.edu/urn-3: HUL.InstRepos:37736804 (accessed on 28 December 2020).

Dechow, Patricia M., Richard G. Sloan, and Amy P. Sweeney. 1995. Detecting Earnings Management. The Accounting Review 70: 193-225.

Dimson, Elroy. 1979. Risk measurement when shares are subject to infrequent trading. Journal of Financial Economics 7: 197-226. [CrossRef]

Eliwa, Yasser, Ahmed Aboud, and Ahmed Saleh. 2019. ESG practices and the cost of debt: Evidence from EU countries. Critical Perspectives on Accounting, 102097. [CrossRef]

Ertugrul, Mine, Jin Lei, Jiaping Qiu, and Chi Wan. 2017. Annual Report Readability, Tone Ambiguity, and the Cost of Borrowing. Journal of Financial and Quantitative Analysis 52: 811-36. [CrossRef]

Fatemi, Ali, Martin Glaum, and Stefanie Kaiser. 2018. ESG performance and firm value: The moderating role of disclosure. Global Finance Journal 38: 45-64. [CrossRef]

Fulton, Mark, Bruce Kahn, and Camilla Sharples. 2013. Sustainable Investing: Establishing Long-Term Value and Performance. SSRN Electronic Journal. Available online: https:/ / ssrn.com/abstract=2222740 (accessed on 28 December 2020). [CrossRef]

Gelb, David S., and Joyce A. Strawser. 2001. Corporate social responsibility and financial disclosures: An alternative explanation for increased disclosure. Journal of Business Ethics 33: 1-13. [CrossRef]

Global Sustainable Investment Alliance. 2018. Global Sustainable Investment Review 2018. Available online: http:/ /www.gsi-alliance. org/wp-content/uploads/2019/03/GSIR_Review2018.3.28.pdf?utm_source= (accessed on 28 December 2020).

Hemingway, Christine A., and Patrick W. Maclagan. 2004. Managers' personal values as drivers of corporate social responsibility. Journal of Business Ethics 50: 33-44. [CrossRef]

Hutton, Amy P., Alan J. Marcus, and Hassan Tehranian. 2009. Opaque financial reports, R2, and crash risk. Journal of Financial Economics 94: 67-86. [CrossRef]

Jin, Li, and Stewart C. Myers. 2006. R2 around the world: New theory and new tests. Journal of Financial Economics 79: 257-92. [CrossRef]

Kim, Jeong-Bon, and Liandong Zhang. 2016. Accounting Conservatism and Stock Price Crash Risk: Firm-level Evidence. Contemporary Accounting Research 33: 412-41. [CrossRef]

Kim, Jeong-Bon, Yinghua Li, and Liandong Zhang. 2011. Corporate tax avoidance and stock price crash risk: Firm-level analysis. Journal of Financial Economics 100: 639-62. [CrossRef]

Kim, Yongtae, Myung Seok Park, and Benson Wier. 2012. Is earnings quality associated with corporate social responsibility? Accounting Review 87: 761-96. [CrossRef]

Kim, Yongtae, Haidan Li, and Siqi Li. 2014. Corporate social responsibility and stock price crash risk. Journal of Banking and Finance 43: 1-13. [CrossRef]

Kim, Jeong-Bon, Leye Li, Louise Yi Lu, and Yangxin Yu. 2016. Financial statement comparability and expected crash risk. Journal of Accounting and Economics 61: 294-312. [CrossRef]

Li, Tao, Cheng Xiang, Zhuo Liu, and Wenwu Cai. 2020. Annual report disclosure timing and stock price crash risk. Pacific Basin Finance Journal 62: 101392. [CrossRef]

Lo, Andrew W., and A. Craig MacKinlay. 1990. An econometric analysis of nonsynchronous trading. Journal of Econometrics 45: 181-211. [CrossRef]

Ministry of the Environment Government of Japan. 2020. For Sustainable Development of All Companies-Activity Guidelines for Sustainable Development Goals (SDGs), 2nd ed.; Tokyo: Ministry of the Environment Government of Japan. Available online: http:/ / www.env.go.jp/policy/sdgs/guides/SDGsguide-honpen_ver2.pdf (accessed on 28 December 2020). (In Japanese)

Oonishi, Junya, and Hiroshi Umeda. 2018. Arguments of Issues about Integration Report. PRI Discussion Paper Series. No.18A11. Available online: https://www.mof.go.jp/pri/research/discussion_paper/ron311.pdfNo (accessed on 28 December 2020). (In Japanese)

PRI. n.d. About the PRI. Available online: https:/ / www.unpri.org/pri/about-the-pri (accessed on 28 December 2020).

Prior, Diego, Jordi Surroca, and Josep A. Tribó. 2008. Are socially responsible managers really ethical? Exploring the relationship between earnings management and corporate social responsibility. Corporate Governance: An International Review 16: 160-77. [CrossRef]

Qontigo. n.d. STOXX ${ }^{\circledR}$ Europe 600. Available online: https://www.stoxx.com/index-details?symbol=SXXP (accessed on 28 December 2020).

United Nations. 2015. United Nations Transforming Our World: The 2030 Agenda for Sustainable Development. Available online: https:/ / sustainabledevelopment.un.org/content/documents/21252030\%20Agenda\%20for\%20Sustainable\%20Development $\%$ 20web.pdf (accessed on 28 December 2020). 
Yoshida, Aya. 2019. The role of Japan for achieving SDGs. Environmental Technology 48: 240-44. (In Japanese) [CrossRef] Yuyama, Tomonor, Youko Shirasu, and Souichirou Moridaira. 2019. ESG Disclosure score and performance. Securities Analysts Journal 57: 72-83. Available online: http:/ / ci.nii.ac.jp/naid/40022042285/ja/ (accessed on 28 December 2020). (In Japanese). 